\title{
КЛАСИФІКАЦІЯ ГАРАНТІЙ ПРАВ ГРОМАДЯН, ЗАСУДЖЕНИХ ДО ПОЗБАВЛЕННЯ ВОЛІ В УКРАЇНІ
}

\author{
ПОЧАНСЬКА Олена Сергї̈вна - доктор юридичних наук, доцент кафедри \\ правового забезпечення господарської діяльності факультету № 6 Харківського \\ національного університету внутрішніх справ \\ ORCID: https://orcid.org/0000-0003-3953-8660 \\ УДК 342.9 \\ DOI 10.32782/LAW.2020.3.26
}

\section{Постановка проблеми}

Поряд із завданням визнання та закріплення прав і свобод громадян, засуджених до позбавлення волі, важливою проблемою 6 їх реальна реалізація, яка потребує належного забезпечення з боку держави за допомогою відповідних адміністративно-правових засобів, які надають усім правам і свободам засудженої особи реального змісту. При цьому наявність низки засобів матеріального і процесуального характеру сама пособі ще не є запорукою якісного забезпечення прав і свобод громадян, засуджених до позбавлення волі в Україні. Їх ефективна реалізація, охорона та захист значною мірою залежать від системи організаційно-правових (інституційних) гарантій, спрямованих на забезпечення прав і свобод засуджених громадян, а також належне виконання відповідних обов'язків органами державної влади та місцевого самоврядування, їх службовими і посадовими особами, на боротьбу 3 правопорушеннями у даній сфері, утвердження загального режиму законності.

Аналіз останніх досліджень і публікацій

Загальнотеоретичні питання змісту та захисту прав людини розглядалися в працях таких вітчизняних і зарубіжних учених, як В. Авер'янов, Ю. Битяк, ᄉ. Глухарьова, О. Аукашева, М. Матузов,
О. Музичука, П. Рабінович, О. Скакун, Ю. Тодика та ін. Права i свободи засуджених, їх дотримання при виконанні кримінального покарання були предметом наукового аналізу С. Бараша, О. Джужи, В. Льовочкіна, О. Лисодіда, Н. Рябих, О. Северин, А. Степанюка, I. Яковець. Окремі аспекти функціонування механізму забезпечення прав засуджених громадян досліджували I. Бородін, М. Гаврильців, T. Заворотченко, I. Ієрусалімова, В. Кравчук, О. Соколенко та ін.

Не вирішені раніше проблеми

Проте, незважаючи на численні праці у цій сфері, дослідженню питання організаційно-правових гарантій прав громадян, засуджених до позбавлення волі, не приділяється достатньої уваги, що й зумовлює актуальність даної статті.

\section{Мета та завдання статті}

Метою статті є дослідження змісту i особливостей організаційно-правових гарантій прав і свобод громадян, засуджених до позбавлення волі в Україні, що передбачає уточнення поняття «юридичні гарантії», загальну характеристику організаційно-правових (інституційних) гарантій, визначення основних видів та аналіз змісту організаційно-правових гарантій прав та свобод громадян, засуджених до позбавлення волі в Україні. 
Наукова новизна дослідження полягає у тому, що стаття є першою науковою працею, у якій запропоновано класифікацію організаційно-правових гарантій прав громадян, засуджених до позбавлення волі.

\section{Виклад основного матеріалу}

У найзагальнішому розумінні гарантії є системою засобів, що сприяють реалізації прав і свобод, охоплюваних законом інтересів та обов’язків [1, с.160]. Довідкова література визначає юридичні гарантії як встановлені законом засоби безпосереднього забезпечення, використання, додержання, виконання і правильного застосування норм права [2, с.123]. Як засоби, умови, способи, що забезпечують здійснення у повному обсязі й всебічну охорону прав i свобод особи, це поняття охоплюе собою всю сукупність об'єктивних і суб'єктивних чинників, спрямованих на практичну реалізацію прав і свобод, на усунення можливих перешкод їх здійснення [3, с.555].

У загальній теорії права правові гарантії класифікують за низкою критеріїв. Проте найбільш обгрунтованим є розподіл усіх юридичних гарантій прав і свобод людини і громадянина відповідно до їх форми на нормативно-правові та організаційно-правові [4, с.8]. Нормативно-правові гарантії прав являють собою сукупність правових норм, за допомогою яких забезпечуються реалізація, порядок охорони і захисту прав та свобод особистості. До нормативно-правових гарантій відносять норми-принципи, юридичну відповідальність та юридичні обов'язки суб'єктів забезпечення прав і свобод громадян, передбачені законодавством. Організаційно-правові гарантії конституційних прав та свобод людини і громадянина - це різноманітна виконавчо-розпорядча, процедурна, контрольна та інша діяльність органів держави, місцевого самоврядування, посадових осіб, громадських організацій у сфері правотворчості та правозастосування, спрямована на створення сприятливих умов для користування громадянами своїми правами і свободами.
У юридичній науці організаційні гарантії визначаються як певний механізм організації та здійснення юридичного забезпечення реалізації, охорони і захисту прав і свобод людини та громадянина [5, c.60], створення сприятливих умов для реального користування громадянами своїми правами і свободами [6, с.40], система заходів процедурного, режимного, контрольного та іншого характеру, зміст якої складають визначення, прийняття та вирішення державою завдань соціального і правового забезпечення діяльності, державний і громадський контроль, обробка інформації, організаційні процедури застосування заходів і зв'язку та ін. [7, c.282].

Усі організаційно-правові гарантії прав і свобод людини та громадянина можуть бути класифіковані за різними підставами. Насамперед, слід зазначити, що інституційна складова загального механізму забезпечення прав і свобод безпосередньо випливає 3 нормативної складової і містить у собі діяльність органів державної влади та місцевого самоврядування, політичних партій і громадських організацій, окремих громадян, що спрямована на реалізацію, охорону та захист прав i свобод людини та громадянина. Тож усі організаційно-правові гарантії прав і свобод можна поділити на ті, які пов'язані 3 функцією їх захисту від імені держави (перш за все, повсякденна робота уповноважених органів виконавчої влади, спрямована на охорону прав і свобод людини і громадянина), та ті, що пов'язані із здійсненням забезпечення прав і свобод людини та громадянина інститутами громадянського суспільства (серед яких слід окремо відзначити діяльність таких інституцій, які створені спеціально з цією метою (адвокатура), такі, для яких дана діяльність є основною (профспілки), та інші (засоби масової інформації, партії, добровільні об'єднання тощо). Відповідно ж до свого змісту, всі організаційно-правові гарантії прав і свобод людини та громадянина найчастіше розподіляють на контрольні, процедурні та організаційно-технічні [7, с.283]. 
Головною складовою адміністративно-правових гарантій прав та свобод людини і громадянина виступає контроль. Так, I. Бородін слушно підкреслює, що саме контроль, як основна гарантія прав та свобод громадян, знаходить свій прояв у своєму соціальному призначенні і поєднуе в собі елементи правоохоронної, правозастосовчої та управлінської діяльності:

а) правоохоронна діяльність спрямована на припинення протиправних дій посадових осіб і притягнення їх до юридичної відповідальності та передбачає вплив на порушників законодавства;

б) правозастосовча діяльність передбачає кваліфікований нагляд за тим, щоб реальна, фактична діяльність державних органів, їх посадових осіб відповідала тому, що встановлено законом, максимально забезпечувала права та свободи громадян;

в) управлінська сутність контрольної діяльності виявляється в правових актах контрольних органів, службових документах $[8$, с.24].

Аналіз чинного законодавства України, що регулює правовий статус осіб, засуджених до позбавлення волі, а також суб'єктів забезпечення їх прав, свобод та законних інтересів, дає змогу виділити наступні види контролю і нагляду у цьому напрямку діяльності:

1) Парламентський контроль. Верховна Рада України здійснює безпосередньо і через створювані нею органи контроль за дотриманням законності в діяльності органів і установ виконання покарань. Відповідно до Закону України «Про Уповноваженого Верховної Ради 3 прав людини», парламентський контроль за додержанням конституційних прав і свобод засуджених та захист їх прав на території України здійснюе Уповноважений Верховної Ради України з прав людини. Метою парламентського контролю за додержанням прав і свобод людини і громадянина 6 :

захист прав і свобод людини та громадянина, проголошених Конституцією України, законами України та міжнародними договорами України; запобігання порушенням прав i свобод людини та громадянина або сприяння їх поновленню;

сприяння приведенню законодавства України про права і свободи людини та громадянина у відповідність з Конституцією України, міжнародними стандартами у цій галузі;

запобігання будь-яким формам дискримінації щодо реалізації людиною своїх прав і свобод;

сприяння правовій інформованості населення та захист конфіденційної інформації про особу та ін. [9, ст.3].

2) Урядовий контроль. Кабінет Міністрів України, як вищий орган у системі органів виконавчої влади, забезпечує виконання Конституції та законів України, актів Президента України, зокрема, щодо забезпечення прав та свобод людини і громадянина [10, ч.1,2 ст.116]. Відповідно до Закону України «Про Кабінет Міністрів України», Кабінет Міністрів України здійснюе постійний контроль за виконанням органами виконавчої влади Конституції України та інших актів законодавства України, вживає заходів щодо усунення недоліків у роботі зазначених органів [11, ст. 19].

3) Судовий контроль. Серед важливих завдань судової гілки влади в Україні, визначених Національною стратегією у сфері прав людини, слід відзначити такі, як забезпечення періодичних перевірок судом законності затримання, позбавлення свободи осіб, а також посилення ефективності судового контролю за підставами позбавлення свободи та ін. [12]. Здійснення у порядку, передбаченому Кримінальним процесуальним кодексом та Законом України «Про судоустрій і статус суддів», судового контролю за дотриманням прав, свобод та інтересів осіб у кримінальному провадженні, покладається на слідчих суддів - суддів суду першої інстанції, а у випадку, передбаченому ст.247 Кримінального процесуального кодексу, - на голів чи інших суддей Апеляційного суду Автономної Республіки Крим, апеляційного суду області, міст Києва та Севасто- 


\section{Цивільне, підприсмницьке, господарське та трудове право}

поля [13, ст.3, 247].

4) Прокурорський нагляд за виконанням кримінальних покарань. Відповідно до Закону України «Про прокуратуру», прокурор здійснює нагляд за додержанням законів в органах і установах виконання покарань при виконанні судових рішень у кримінальних справах, а також при застосуванні інших заходів примусового характеру, пов'язаних з обмеженням особистої свободи громадян [14, ст.22]. До основних напрямків діяльності органів прокуратури віднесено забезпечення нагляду за додержанням:

прав і свобод людини, загальних інтересів суспільства і держави при виконанні покарань та інших заходів примусового характеру, пов'язаних 3 обмеженням особистої свободи, відповідно до законів України, міжнародних договорів, згода на обов'язковість яких надана Верховною Радою України;

законодавства щодо запобігання катуванням чи нелюдському або такому, що принижує гідність, поводженню із засудженими;

- визначених законодавством вимог режиму, порядку та умов відбування покарань засудженими особами та ін. [15, п.2].

5) Відомчий контроль. Згідно зі ст.23 Кримінально-виконавчого кодексу України, за діяльністю органів і установ виконання покарань здійснюеться відомчий контроль вищестоящими органами управління і посадовими особами центрального органу виконавчої влади, що реалізує державну політику у сфері виконання кримінальних покарань [14]. Як головний орган у системі центральних органів виконавчої влади, що здійснює державну політику у сфері виконання кримінальних покарань, Міністерство юстиції України забезпечує контроль за дотриманням прав людини і громадянина, вимог законодавства щодо виконання і відбування кримінальних покарань, реалізацією законних прав та інтересів засуджених осіб [16]. Також Міністерством юстиції України спрямовується і координується діяльність Державної кримінально-виконавчої служби України, до завдань якої відноситься організація контролю за дотриманням прав людини і громадянина, вимог законодавства щодо виконання і відбування кримінальних покарань, реалізація законних прав та інтересів засуджених осіб.

6) Оперативно-розшуковий контроль. Відповідно до Закону України «Про оперативно-розшукову діяльність», оперативними підрозділами органів і установ виконання покарань у колоніях здійснюється оперативно-розшукова діяльність, основним завданням якої 6 пошук і фіксація фактичних даних про протиправну діяльність окремих осіб та груп з метою: забезпечення безпеки засуджених, персоналу колоній та інших осіб; попередження і виявлення злочинів, вчинених у колоніях, а також порушень встановленого порядку відбування покарання; вивчення причин і умов, що сприяють вчиненню злочинів та інших правопорушень; надання правоохоронним органам, які здійснюють оперативно-розшукову діяльність або кримінальне провадження, допомоги в розкритті, припиненні та попередженні злочинів [14, ст.104].

7) Контроль, який здійснюється шляхом та під час відвідування установ виконання покарань. Відповідно до норм кримінально-виконавчого законодавства, право на відвідування установ виконання покарань для здійснення контролю та проведення перевірок мають:

- Президент України або спеціально уповноважені ним представники;

- Прем'єр-міністр України або спеціально уповноважені ним представники;

Уповноважений Верховної Ради України з прав людини або спеціально уповноважені ним представники;

голова, заступники голови та члени Комісії при Президентові України у питаннях помилування;

Міністр юстиції України або спеціально уповноважені ним представники;

Міністр внутрішніх справ України, Голова Національної поліції або спеціально уповноважені ними представники; 
- члени Европейського комітету 3 питань запобігання катуванням чи нелюдському або такому, що принижує гідність, поводженню чи покаранню;

Голова Ради міністрів Автономної Республіки Крим, голови місцевих державних адміністрацій, на території яких вони розташовані, або спеціально уповноважені ними представники;

народні депутати України, їх помічники-консультанти, депутати Верховної Ради Автономної Республіки Крим та депутати місцевих рад;

Генеральний прокурор, а також уповноважені ним прокурори і прокурори, які здійснюють на відповідній території нагляд за додержанням законів при виконанні судових рішень у кримінальних справах, а також при застосуванні інших заходів примусового характеру, пов'язаних 3 обмеженням особистої свободи громадян;

голова, заступник голови та члени спостережної комісії, які здійснюють організацію громадського контролю за дотриманням прав і законних інтересів засуджених під час виконання кримінальних покарань;

сільський, селищний, міський голова або спеціально уповноважені ними представники - на території відповідної місцевої ради;

члени громадських рад при центральному органі виконавчої влади, що реалізує державну політику у сфері виконання кримінальних покарань, та його територіальних підрозділах - на відповідній території [14, ч.1 ст.24].

Представники громадських організацій, експерти, учені та фахівці, залучені Уповноваженим Верховної Ради України 3 прав людини на договірних засадах до виконання функцій національного превентивного механізму, відвідують установи виконання покарань на підставі окремого письмового доручення Уповноваженого [14, п.7 ч. 1 ст.24].

8) Громадський контроль за дотриманням прав засуджених під час виконання кримінальних покарань. Громадський контроль за дотриманням прав засуджених під час виконання кримінальних покарань здійснюють спостережні комісії, які діють на підставі Кримінально-виконавчого кодексу та Положення про спостережні комісії. У випадках, встановлених законодавством України, громадський контроль за дотриманням прав засуджених під час виконання кримінальних покарань можуть здійснювати громадські об'єднання. Об’єднання громадян та засоби масової інформації, неурядові правозахисні організації, релігійні та благодійні організації, окремі особи в порядку, встановленому цим Кодексом і законами України, можуть надавати допомогу органам та установам виконання покарань у виправленні засуджених і проведенні соціально-виховної роботи [14, ст.25]. Зокрема, предметом контролю правозахисних організацій 6 поточна державна політика в галузі прав людини, рішення, дії державних органів та їх посадових осіб, внаслідок яких порушуються права людини і основоположні свободи, або створюються перешкоди для здійснення цих прав і свобод.

9) Міжнародний контроль. Як відзначають експерти, міжнародний контроль 6 «важливим і необхідним у сфері виконання кримінальних покарань і забезпеченні прав осіб, які утримуються в місцях фактичного обмеження або позбавлення волі та засуджених» $[17$, с.50]. Міжнародний контроль за дотриманням прав засуджених та діяльністю кримінально-виконавчих установ здійснюється міжнародними організаціями на підставі сучасних міжнародних документів у галузі прав людини, що є невід'ємною складовою національної системи правового забезпечення прав громадян, засуджених до позбавлення волі в Україні. До найбільш впливових міжнародних організацій у цій сфері належать Комітет ООН проти катувань та Европейський Комітет із запобігання катуванням та поганому поводженню. Так, зокрема, відповідно до норм Европейської конвенції запобігання катуванням чи нелюдському або такому, що принижує гідність, поводженню чи покаранню [18, ст.2], члени 


\section{Цивільне, підприсмницьке, господарське та трудове право}

цих організацій мають право відвідувати будь-які місця, де утримуються особи, позбавлені волі 3 метою дослідження умов тримання, вивчення фактів, що можуть свідчити про застосування тортур до осіб, та інформування широкої громадськості і органів державної влади про стан дотримання прав людини, а також про виявлені факти катувань.

Важливе місце у діяльності органів виконавчої влади по забезпеченню прав та свобод людини і громадянина займають адміністративні процедури (зокрема, процедури участі відповідних суб'єктів у тих чи інших заходах щодо: ресоціалізації засуджених осіб, укладання угод (договорів) про співпрацю, надання юридичних, психологічних, реабілітаційних та інших послуг засудженим особам, реалізації соціально-реабілітаційних програм та профілактичних заходів щодо запобігання вчинення злочинів тощо). 3 одного боку, такі процедури сприяють загальному підвищенню ефективності управлінської діяльності, а 3 іншого, - забезпечують необхідну послідовність у реалізації громадянами своїх прав і свобод. Раціонально побудовані та детально визначені у законодавстві процедури діяльності державних органів становлять собою ефективну гарантію забезпечення прав і свобод громадян, є необхідною складовою механізму їх захисту від зловживання владними повноваженнями й некомпетентності у діяльності службових і посадових осіб органів державної влади та органів місцевого самоврядування.

До системи організаційно-правових гарантій прав і свобод людини і громадянина також слід віднести й такі засоби, як моніторингова діяльність та соціально-психологічна й профілактична діяльність державних і недержавних суб'єктів, спрямована на подолання психологічної деформації засуджених, їх соціальну адаптацію, відновлення соціального статусу та реінтеграцію у суспільство шляхом підвищення суспільно-політичної свідомості засуджених громадян (зокрема, формування в них свідомого ставлення до викорис- тання прав і свобод, а також виконання обов’язків), підвищення рівня правової культури, здобуття освіти, формування необхідних умінь і навичок, що допоможуть успішно реінтегруватися у суспільство.

\section{Висновки}

Отже, основною організаційно-правовою гарантією додержання, реалізації та захисту прав і свобод громадян, засуджених до позбавлення волі, є державний контроль. Проте все більшого значення у сучасних умовах демократизації публічних відносин та децентралізації державної влади набуває й громадський контроль за додержанням та реалізацією прав і свобод громадян, засуджених до позбавлення волі в Україні. Нарешті, ще одним невід'ємним елементом загальної системи гарантій прав і свобод громадян, засуджених до позбавлення волі, 6 міжнародний контроль за дотриманням прав засуджених та діяльністю кримінальновиконавчих установ, що здійснюеться відповідними міжнародними організаціями на підставі норм сучасних міжнародних документів у галузі прав людини. До інших видів організаційно-правових гарантій прав і свобод громадян, засуджених до позбавлення волі, віднесено процедурні гарантії, що сприяють загальному підвищенню ефективності управлінської діяльності та забезпечують необхідну послідовність у реалізації засудженими своїх прав i свобод, а також моніторингову діяльність та різноманітну соціально-психологічну й профілактичну діяльність державних і недержавних суб'єктів забезпечення прав i свобод громадян, засуджених до позбавлення волі в Україні.

\section{Лiтература}

1. Виконавча влада і адміністративне право / за заг. ред. В. Б. Авер'янова. - К. : Ін-Юре, 2002. - 668 с.

2. Головченко В. В. Юридична термінологія : довідник / В. В. Головченко, В. С. Ковальський. - К. : Юрінком Інтер, 1998. - 219 c. 
3. Аисенков С. $\lambda$. Гарантії прав та свобод людини і громадянина /С. А. Аисенков, А. П. Таранов // Юридична енциклопедія: В 6 т. / редкол.: Ю. С. Шемшученко (відп. ред.) та ін. - Т. 1: А-Г. - К.: «Укр. енцикл.», 1998. - 672 с.

4. Пушкіна О. В. Конституційний механізм забезпечення прав людини i громадянина в Україні: проблеми теорії і практики: автореф. дис. на здобуття наук. ступеня докт. юрид. наук : спец.: 12.00.02 «Конституційне право» / О.В.Пушкіна; Нац. юрид. акад. України ім. Я. Мудрого. - X., 2008. - 48 c.

5. Рабінович П. М. Права людини і громадянина: навч. посіб. / П. М. Рабінович, М. І. Хавронюк. - К. : Атіка, 2004. - 464 с.

6. Гаврильців М. Т. Організаційноправові гарантії конституційного права ^юдини та громадянина. на судовий захист у сфері публічних правовідносин / М. Т. Гаврильців // Наук. вісник Міжнар. гуманіт. ун-ту: Серія: Юриспруденція. - 2016. - № 22. - С.38-41 [Електронний peсурс]. - Режим доступу: http://vestnikpravo.mgu.od.ua/archive/ juspradenc22/10. pdf.

7. Теория государства и права : курс лекций / под ред. Н. И. Матузова иА. В. Малько. - М. : Юристъ, 1999. - 672 с.

8. Бородін I. $\Lambda$. Адміністративноправові способи захисту прав та свобод людини і громадянина : автореф. дис. на здобуття наук. ступеня доктора юрид. наук : спец. 12.00.07 «Адміністративне право i процес. Фінансове право. Інформаційне право» / I.ᄉ. Бородін ; Національний ун-т внутрішніх справ. Харків, 2004. - 37 с.

9. Про Уповноваженого Верховної Ради з прав людини : Закон України : від 23.12.1997 р., № 776/97-ВР // Відомості Верховної Ради України. - 1998. - № 20. - Ст.99.

10. Конституція України // Відомості Верховної Ради України. - 1996. - № 30. Cт. 141.

11. Про Кабінет Міністрів України : Закон України : від 27.02.2014 р., № 794VII // Відомості Верховної Ради. - 2014. № 13. - Ст.222.
12. Про затвердження Національної стратегіï у сфері прав людини : Указ Президента України : від 25.08.2015 р.,№ 501/2015 // Офіційний вісник Президента України. - 2015. - № 20. Ст.1203.

13. Кримінальний процесуальний кодекс України : Закон України : від 13.04.2012 р., № 4651-VI // Відомості Верховної Ради України. - 2013. - № 9-10, № 11-12, № 13. - Ст.88.

14. Кримінально-виконавчий кодекс України : Закон України : від 11.07.2003 р., № 1129-IV // Відомості Верховної Ради України. - 2004. - № 3-4. - Ст. 21.

15. Про організацію діяльності прокурорів 3 нагляду за додержанням законів при виконанні судових рішень у кримінальних справах, а також при застосуванні інших заходів примусового характеру, пов'язаних 3 обмеженням особистої свободи громадян : Наказ Генеральної прокуратури України : від 20.04.2016 р., № 161 [Електронний ресурс]. - Режим доступу: http://www. gp.gov.ua/ua/gl.html?_m=publications\&_ $\mathrm{t}=$ rec\&id $=94102$.

16. Про затвердження Положення про Міністерство юстиції України : Постанова Кабінету Міністрів України : від 02.07.2014 p., № 228 // Офіційний вісник України. 2014. - № 54. - Ст. 1455.

17. Проблеми забезпечення прав засуджених у кримінально-виконавчій системі України. / В. А. Бадира, О. П. Букалов, А. П. Гель, М. В. Романов, I. С. Яковець; За заг. ред. С. Ю. Захарова. Харківська правозахисна група. - Х. : Права людини, 2011. - 368 c.

18. Европейська

Конвенція про запобігання катуванням чи нелюдському або такому, що принижує гідність, поводженню чи покаранню : Міжнародний документ Ради Европи : від 26.11.1987 р. [Електронний ресурс]. Режим доступу: http://zakon2.rada.gov.ua/ laws/show/995_068. 


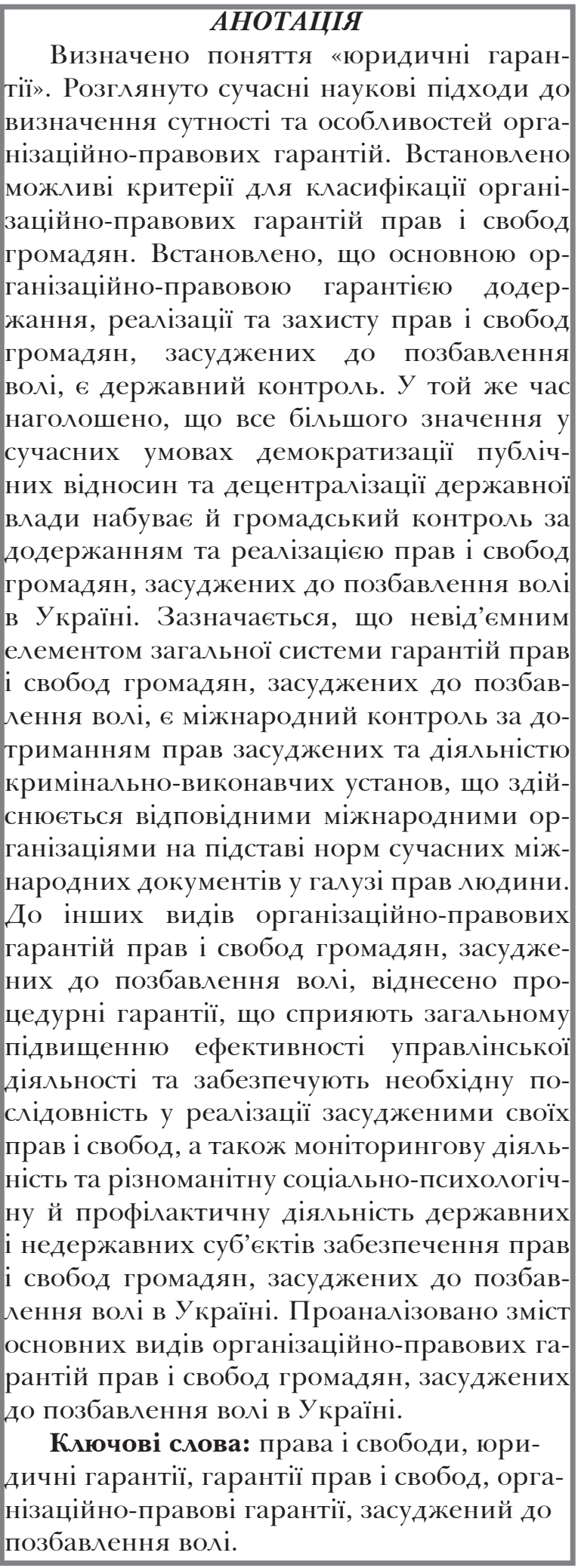

\section{SUMMARY}

The concept of "legal guarantees" is defined. Modern scientific approaches to determining the nature and features of organizational and legal guarantees are considered. Possible criteria for classification of organizational and legal guarantees of rights and freedoms of citizens are established. It is established that the main organizational and legal guarantee of observance, realization and protection of the rights and freedoms of citizens sentenced to imprisonment is state control. At the same time, it was emphasized that in the current conditions of democratization of public relations and decentralization of state power, public control over the observance and realization of the rights and freedoms of citizens sentenced to imprisonment in Ukraine is becoming increasingly important. It is noted that an integral part of the general system of guarantees of the rights and freedoms of citizens sentenced to imprisonment is international control over the rights of convicts and the activities of penitentiaries, carried out by relevant international organizations on the basis of modern international human rights instruments. Other types of organizational and legal guarantees of the rights and freedoms of citizens sentenced to imprisonment include procedural guarantees that contribute to the overall efficiency of administrative activities and ensure the necessary consistency in the implementation of convicts' rights and freedoms, as well as monitoring activities and various socio-psychological and preventive activity of state and non-state subjects of ensuring the rights and freedoms of citizens sentenced to imprisonment in Ukraine. The content of the main types of organizational and legal guarantees of the rights and freedoms of citizens sentenced to imprisonment in Ukraine is analyzed.

Key words: rights and freedoms, legal guarantees, guarantees of rights and freedoms, organizational and legal guarantees, sentenced to imprisonment. 